\title{
Genotoxicity Induced by Cellular Uptake of Chitosan Nanoparticles in Human Dental Pulp Cells
}

\author{
Rami Alhomrany ${ }^{1}$, Chang Zhang ${ }^{2}$, Laisheng Chou ${ }^{2, *}$ \\ ${ }^{1}$ Department of Endodontics, Boston University Henry M Goldman School of Dental Medicine, Boston, USA \\ ${ }^{2}$ Department of Restorative Sciences and Biomaterials, Boston University Henry M Goldman School of Dental Medicine, Boston, USA
}

Email address:

rhomrany@bu.edu (R. Alhomrany)

${ }^{*}$ Corresponding author

\section{To cite this article:}

Rami Alhomrany, Chang Zhang, Laisheng Chou. Genotoxicity Induced by Cellular Uptake of Chitosan Nanoparticles in Human Dental Pulp Cells. International Journal of Materials Science and Applications. Vol. 10, No. 4, 2021, pp. 79-86. doi: 10.11648/j.ijmsa.20211004.11

Received: June 4, 2021; Accepted: June 21, 2021; Published: July 15, 2021

\begin{abstract}
Objective: Recent in vitro studies have shown that chitosan nanoparticles in several root canal sealers, intracanal medicament, and irrigation solutions could enhance the antimicrobial activity. However, the nanotoxicity of chitosan has not been fully studied. The aim of this study was to evaluate cellular uptake and genotoxicity of various sizes and concentrations of chitosan nanoparticles cultured with human dental pulp cells. Methods: Human dental pulp cells were derived from human dental pulp tissues and cultured for 24 hours with $50 \mathrm{~nm}$ and $318 \mathrm{~nm}$ FITC-tagged chitosan nanoparticles in concentrations: 0.1 $\mathrm{mg} / \mathrm{mL}, 0.5 \mathrm{mg} / \mathrm{mL}$, and $2 \mathrm{mg} / \mathrm{mL}$ as study groups, and $0 \mathrm{mg} / \mathrm{mL}$ as a control. The fluorescence intensity of the FITC tagged chitosan nanoparticles was measured using a spectrophotometer to determine the cellular uptake. Genotoxicity was assessed by the Cytokinesis-block micronucleus method and by measuring the fluorescent intensity of the phosphorylated H2AX nuclear foci. Statistical analysis was performed using One-Way ANOVA, post-hoc Tukey, and Chi-square tests. Results: Chitosan nanoparticles were able to internalize the human dental pulp cells and significantly induced micronuclei, nuclear buds, and $\mathrm{pH} 2 \mathrm{AX}$ foci at concentrations of $0.5 \mathrm{mg} / \mathrm{mL}$ and $2 \mathrm{mg} / \mathrm{mL}$ as compared to $0.1 \mathrm{mg} / \mathrm{mL}(P<0.01)$ and control group $(P<0.01)$. At both concentrations, $0.5 \mathrm{mg} / \mathrm{mL}$ and $2 \mathrm{mg} / \mathrm{mL}, 50 \mathrm{~nm}$ chitosan significantly induced higher proportions of micronuclei ( $P=0.001)$, nuclear buds $(P=0.009)$, and $\mathrm{pH} 2 \mathrm{AX}$ nuclear foci $(P=0.00004)$ as compared to $318 \mathrm{~nm}$ chitosan. Conclusion: 50 $\mathrm{nm}$ and $318 \mathrm{~nm}$ chitosan nanoparticles at concentrations $0.5 \mathrm{mg} / \mathrm{mL}$ and $2 \mathrm{mg} / \mathrm{mL}$ penetrated human dental pulp cells and induced genotoxicity in dose-dependent and size-associated manners.
\end{abstract}

Keywords: Chitosan, Nanoparticles, Dental Pulp, Cellular Uptake, Genotoxicity

\section{Introduction}

Chitosan is a cationic polysaccharide derived from another polysaccharide called Chitin, which exists naturally within the exoskeleton of the crustaceans and shrimps. The inherent antimicrobial property of chitosan nanoparticles has attracted much attention especially in endodontic, periodontal and preventive dentistry fields. The active amino groups provide chitosan nanoparticles with a cationic charge which allows chitosan nanoparticles to electrostatically interact with the negatively charged membrane of the bacteria, resulting in leakage of essential components and consequently leading to bacterial death [1]. Studies have shown that these nanoparticles can significantly reduce the biofilms of enterococcus faecalis and streptococcus mutans, bacteria which are associated with periapical infections and dental carries, respectively [2,3]. This antimicrobial property was exploited by researchers to improve the antibacterial activity of several dental materials such as zinc oxide eugenol sealer, epoxy resin sealer, calcium hydroxide medicament, and composite restoration [2, 4-6]. In other context, immune cells like macrophages, are not sufficient enough in clearing out the nanoparticles completely from the human body [7]. A study highlighted that chitosan nanoparticles undergo exocytosis after being engulfed by macrophages within few hours, which indicate that nanoparticles remain in tissues for longer time [7]. In preventive dentistry, Niousha et al, demonstrated a method of entrapping fluoride into chitosan nanoparticles [8]. In their study, it was shown that the 
entrapment efficiency reached up to $70 \%$ and the chitosan nanoparticles constantly released the entrapped fluoride over 24 hours which makes these nanoparticles a promising fluoride carrier that could be utilized to decrease dental caries. Another study showed the ability of modified chitosan nanoparticles to serve as an indirect dental pulp capping material as it plays a role in the remineralization of a demineralized dentin in a deep caries tooth model [9]. In the aforementioned clinical applications, chitosan nanoparticles come in close contact with dental pulp via passage through the ubiquitous dentinal tubules. However, there is limited knowledge regarding chitosan nanoparticles biocompatibility with hDPCs cells, therefore, it is a pressing issue to determine the most appropriate concentration and size of chitosan nanoparticles to be utilized without causing any hazardous effect to the dental pulp. Therefore, this study was designed to evaluate cellular uptake and genotoxicity of different sizes and concentrations of chitosan nanoparticles cultured with human dental pulp cells for 24 hours.

\section{Materials and Methods}

\subsection{Cell Culture}

Under IRB approval, dental pulp explants were isolated from freshly extracted pristine third molars provided from 15 to 18 -year-old female patients undergoing routine third molar extraction at the oral surgery clinic at Boston University. The hDPCs were cultured according to the protocol published by Stanislawski et al., with modifications [10]. The dental pulp explants were isolated from teeth and transferred into a 25$\mathrm{cm}^{2}$ culture flask (Thermo Fisher Scientific, USA) containing Basal Medium Eagle`s (BME) culture medium supplemented with $10 \%$ fetal bovine serum (Atlanta Biologicals), 100 $\mathrm{U} / \mathrm{mL}$ of Penicillin (Gibco), $100 \mathrm{mg} / \mathrm{mL}$ streptomycin (Gibco), and $0.25 \mathrm{ug} / \mathrm{mL}$ amphotericin-B (Gibco). The hDPCs were incubated in humidified atmosphere at $37^{\circ} \mathrm{C}$ with $5 \% \mathrm{CO}_{2}$ (Thermo Fisher Scientific, USA) and cultured up to the second passage. The cells were detached after reaching $80 \%$ confluence using $0.05 \%$ Trypsin-EDTA (Thermo Fisher Scientific, USA), centrifuged (TJ-6 Beckman Centrifuge) for $5 \mathrm{~min}$ at $1000 \mathrm{rpm}$, counted using hemocytometer and then were utilized for the experiments.

\subsection{Preparation and Characterization of Nanoparticles}

Chitosan nanoparticles were prepared by the ionic gelation method as described by Calvo with modifications [11]. According to the FDA and the European commission, nanoparticles can be defined as a material that contains $50 \%$ or more particles below the size $100 \mathrm{~nm}$. Therefore, in the present study, nanoparticles smaller and larger than $100 \mathrm{~nm}$ were produced in order to investigate the nano-effect. Chitosan powder (Medium Molecular Weight, 190,000-310,000 Da, 85\% degree of deacetylation, Sigma-Aldrich, USA) at masses of 50 $\mathrm{mg}$ and $300 \mathrm{mg}$ were dissolved in $0.1 \%(\mathrm{v} / \mathrm{v})$ acetic acid to create chitosan solutions at concentrations of $0.5 \mathrm{mg} / \mathrm{mL}$ and 3 $\mathrm{mg} / \mathrm{mL}$, sequentially. The $\mathrm{pH}$ of chitosan solutions was raised to
7 using $1 \mathrm{~mol} / \mathrm{L}$ sodium hydroxide $(\mathrm{NaOH})$. Both chitosan solutions were then filtered and stirred with $0.16 \mathrm{mg} / \mathrm{mL}$ and $0.60 \mathrm{mg} / \mathrm{mL}$ Sodium-triphosphate solutions (Sodium-TPP) (Fisher Scientific, USA) for one hour to produce $50 \mathrm{~nm}$ and 318 $\mathrm{nm}$ nanoparticles, respectively [12]. After stirring, $2 \mathrm{mg}$ of nanoparticles were collected by centrifuging the chitosan-TPP solutions at $13000 \mathrm{rpm}$ for 4 minutes. The supernatant was discarded and the pellet, which contains $2 \mathrm{mg}$ of nanoparticles, were suspended in various volumes of BME cell culture medium to create concentrations $0.1 \mathrm{mg} / \mathrm{mL}, 0.5 \mathrm{mg} / \mathrm{mL}$, and 2 $\mathrm{mg} / \mathrm{mL}$. These concentrations were chosen because they possess antibacterial property according to several published studies. Then, all nanoparticles were sonicated at $60 \%$ amplitude for 5 minutes for better dispersion. Nanoparticles agglomeration was monitored using the same method reported previously [13]. Briefly, size distribution and the zeta potential were assessed twice by Dynamic Light Scattering (90 Plus Particle Size Analyzer, NY, USA), immediately after nanoparticles suspension, and once again after three days to assess particles agglomerations. Morphological assessment of the nanoparticles was carried using a Transmission Electron Microscope (Tecani Osiris).

\subsection{Cellular Uptake of FITC-Tagged-Chitosan Nanoparticles}

Chitosan was labeled with fluorescein isothiocyanate (FITC) stain and cultured with hDPCs to investigate the nanoparticles internalization. The concept behind labeling chitosan with FITC stain is based on the stable covalent interaction between amino groups of chitosan and isothiocyanate $\operatorname{root}(\mathrm{N}=\mathrm{C}=\mathrm{S})$ of FITC [14]. Chitosan solutions at concentrations $0.5 \mathrm{mg} / \mathrm{mL}$ and 3 $\mathrm{mg} / \mathrm{mL}$ were prepared as mentioned previously. Both chitosan solutions were then stirred with $10 \mathrm{~mL}$ of $2 \mathrm{mg} / \mathrm{mL}$ FITC solution overnight in the dark to produce FITC-tagged chitosan. Thereafter, FITC-tagged nanoparticles at sizes $50 \mathrm{~nm}$ and 318 $\mathrm{nm}$ were prepared using the same ionic gelation method as mentioned previously. Centrifugation was utilized at $13000 \mathrm{rpm}$ for 4 minutes to collect $2 \mathrm{mg}$ of FITC-tagged nanoparticles. In order to discard any unreacted FITC, the collected FITC-tagged nanoparticles were resuspended in distilled water and centrifuged several times until no florescence was observed in the supernatant, as measured by spectrophotometer. The pellet, which contains $2 \mathrm{mg}$ of chitosan-FITC nanoparticles, was then resuspended in various volumes of culture media to create concentrations, $0.1 \mathrm{mg} / \mathrm{mL}, 0.5 \mathrm{mg} / \mathrm{mL}$, and $2 \mathrm{mg} / \mathrm{mL}$. The nanoparticles were then cultured in 96-well plates with hDPCs at a density of $1.5 \times 10^{4}$ cells per well for 24 hours. Thereafter, the media were discarded and the cells were incubated with trypan blue for a minute to quench extracellular fluorescence to distinguish between the internalized nanoparticles and those which remained in the extracellular milieu [15]. The intensity of the FITC was then measured using a fluorescence spectrophotometer $(\mathrm{Ex} / \mathrm{Em}=495 / 519 \mathrm{~nm})$. For visualization by epifluorescence microscope, the cells were fixed using $10 \%$ formalin and the nuclei were counterstained with 4', 6diamidino-2-phenylindole (DAPI). The internalized nanoparticles were observed microscopically at $40 \mathrm{X}$ 
magnification.

\subsection{PH2AX Immunofluorescence}

DNA double strand breaks were assessed by evaluating the level of phosphorylated $\mathrm{H} 2 \mathrm{AX}$ histones as described before with modifications [16]. Briefly, human dental pulp cells were seeded in 96-well plates at a density of $1.5 \times 10^{4}$ cells per well and were grown overnight in a humidified atmosphere at $37^{\circ} \mathrm{C}$ with $5 \% \mathrm{CO}_{2}$. The cells in the study groups were then exposed to $50 \mathrm{~nm}$ and $318 \mathrm{~nm}$ sized chitosan nanoparticles at concentrations of $0.1 \mathrm{mg} / \mathrm{mL}, 0.5 \mathrm{mg} / \mathrm{mL}$, and $2 \mathrm{mg} / \mathrm{mL}$, while cells of the control group were incubated in culture medium without nanoparticles. After 24 hours, the cells in all groups were washed with phosphate buffer solution, fixed with $10 \%$ neutral buffered formalin, permeabilized by Triton X-100 for 15 minutes, and then blocked using blocking buffer $(0.25 \mathrm{~g}$ of bovine serum albumin in $25 \mathrm{~mL}$ PBS) for 60 minutes. Thereafter, the phosphorylated $\mathrm{H} 2 \mathrm{AX}$ histones were probed by incubating the cells with mouse monoclonal anti$\mathrm{pH} 2 \mathrm{AX}$ primary antibodies for 60 minutes followed by adding florescence-labeled anti-mouse secondary antibodies for another 60 minutes in the dark to facilitate the visualization of the phosphorylated H2AX nuclear foci. The cells were then washed four times with PBS and counterstained by DAPI stain for 10 minutes. The intensity of the phosphorylated $\mathrm{H} 2 \mathrm{AX}$ histones was measured using a florescence spectrophotometer $(\mathrm{Ex} / \mathrm{Em}=555 / 565 \mathrm{~nm})$. To calculate the percentage of $\mathrm{pH} 2 \mathrm{AX}$ fluorescence intensity, the data from the spectrophotometer was then plugged into the following equation: Florescence intensity of the control group - florescence intensity of the test group=the florescence intensity of control group X 100. In addition, florescence images of human dental pulp cells were obtained at $40 \mathrm{X}$ magnification using the Nikon deconvolution widefield epifluorescence System.

\subsection{Cytokinesis Block Micronucleus (CBMN) Assay}

Chromosomal damage in hDPCs exposed to various sizes and concentrations of CS-nanoparticles was assessed using a cytokinesis-block micronucleus assay. The cells were plated in 96-well plates at the same density and exposed to the same sizes and doses of CS-nanoparticles considered for the pH2AX experiment. After 24 hours of nanoparticles exposure, cell division was blocked by adding $6 \mathrm{microg} / \mathrm{mL}$ cytochalasin-b for 18 hours. Thereafter, the cells were washed with PBS, fixed with $10 \%$ formalin, and stained with DAPI stain. Using the epifluorescence microscope at a magnification of $40 \mathrm{X}$, the frequencies of micronuclei and nuclear buds were recorded in one thousand binucleated cells per well, following the same protocol established by Fenech [17].

\subsection{Statistical Analysis}

All experiments were performed at least in triplicate. Utilizing JMP software (Version pro 14). One-way ANOVA and post hoc Tukey tests were used for analyzing the data of cellular uptake and $\mathrm{pH} 2 \mathrm{AX}$ experiments. For the data obtained from the CBMN experiment, a Chi-square test was implemented using the same software. The difference was considered significance when the $\mathrm{P}$ value was below 0.05 .

\section{Results}

\subsection{Characterizations of Chitosan Nanoparticles}

DLS report showed that the nanoparticles size distribution was similar to the data published in a previous work [13]. Briefly, the size distribution of the smaller particles group, immediately after ultrasonic cavitation in culture medium, ranged from $25 \mathrm{~nm}$ up to $116 \mathrm{~nm}$ with a median of $54 \mathrm{~nm}$ and a mean of $50 \pm 16 \mathrm{~nm}$. After three days from ultrasonic cavitation, the sizes distribution ranged from $26 \mathrm{~nm}$ up to 133 $\mathrm{nm}$ with a median of $60 \mathrm{~nm}$ and a mean of $67 \pm 11 \mathrm{~nm}$. For the larger particles group, the distribution of sizes ranged from $107 \mathrm{~nm}$ up to $685 \mathrm{~nm}$ with a median of $271 \mathrm{~nm}$ and a mean of $318 \pm 20 \mathrm{~nm}$ immediately after ultrasonic cavitation in culture medium. Three days later, the particles sizes distribution had changed slightly to be from $125 \mathrm{~nm}$ up to $740 \mathrm{~nm}$ with a median of 305 and a mean of $350 \pm 23 \mathrm{~nm}$. Such findings point out the nanoparticles stability with no significant agglomeration observed within three days after sonication treatment. The zeta-potential was $38.2 \mathrm{mV}$ and $35.6 \mathrm{mV}$ for groups $50 \mathrm{~nm}$ and $318 \mathrm{~nm}$, respectively. TEM images further confirmed the particle size to be $50 \mathrm{~nm}$ for the smaller group and $350 \mathrm{~nm}$ for the larger one as shown in Figure 1 (A, B).

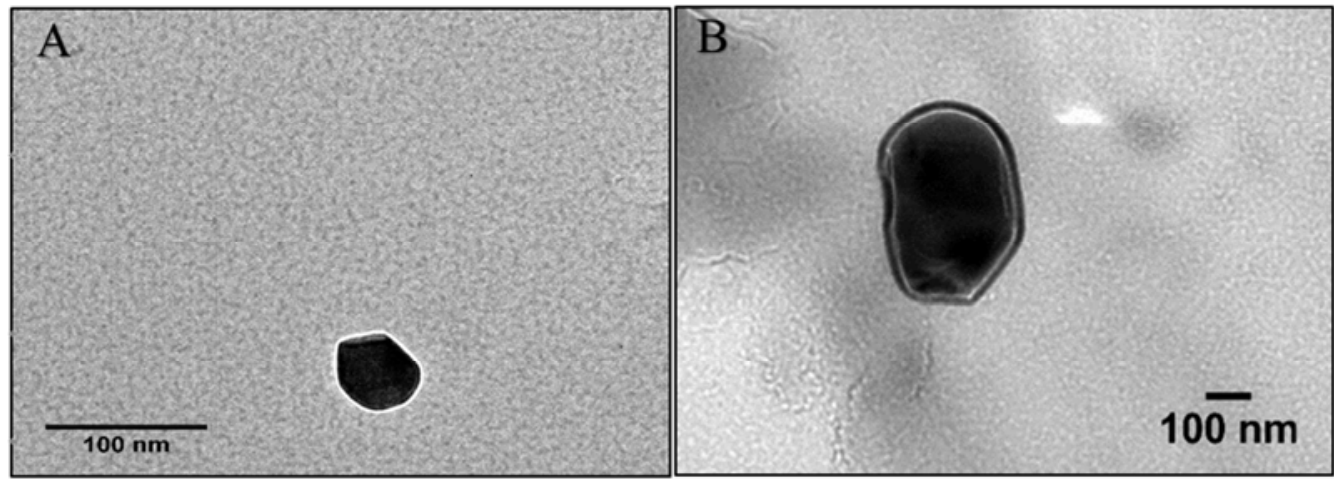

Figure 1. TEM confirms the particle sizes to be $50 \mathrm{~nm}$ for the smaller group (A), and $350 \mathrm{~nm}$ for the larger group (B). 


\subsection{Cellular Uptake of Various Sizes and Concentrations of Chitosan-FITC Nanoparticles}

The uptake of various sizes and concentrations of FITCchitosan nanoparticles was quantified and visualized as seen in Figure 2 (A, B, and C). Only limited cellular uptake was noted at a loading concentration of $0.1 \mathrm{mg} / \mathrm{mL}$ as compared to the control and other treated groups. When the loading concentration was increased up to $0.5 \mathrm{mg} / \mathrm{mL}$ and $2 \mathrm{mg} / \mathrm{mL}$, the cellular uptake was clearly evident. As quantified by florescence spectrophotometer, the cellular uptake of 2 $\mathrm{mg} / \mathrm{mL}$ CS-nanoparticles was significantly higher than 0.5 $\mathrm{mg} / \mathrm{mL}$ for both groups, $50 \mathrm{~nm}$ and $318 \mathrm{~nm}(\mathrm{P}<0.05)$. Also, $50 \mathrm{~nm}$ CS-nanoparticles internalized the cells more significantly as compared with $318 \mathrm{~nm}$ for both concentrations, $\quad 0.5 \mathrm{mg} / \mathrm{mL}$ and $2 \mathrm{mg} / \mathrm{mL} \quad(\mathrm{P}<0.05)$. Additionally, epifluorescence microscope revealed that 50 $\mathrm{nm}$ chitosan nanoparticles accumulated in the cytoplasm and potentially penetrated the nuclei of human dental pulp cells remarkably as compared to $318 \mathrm{~nm}$, in Figure 2 (B, and C).
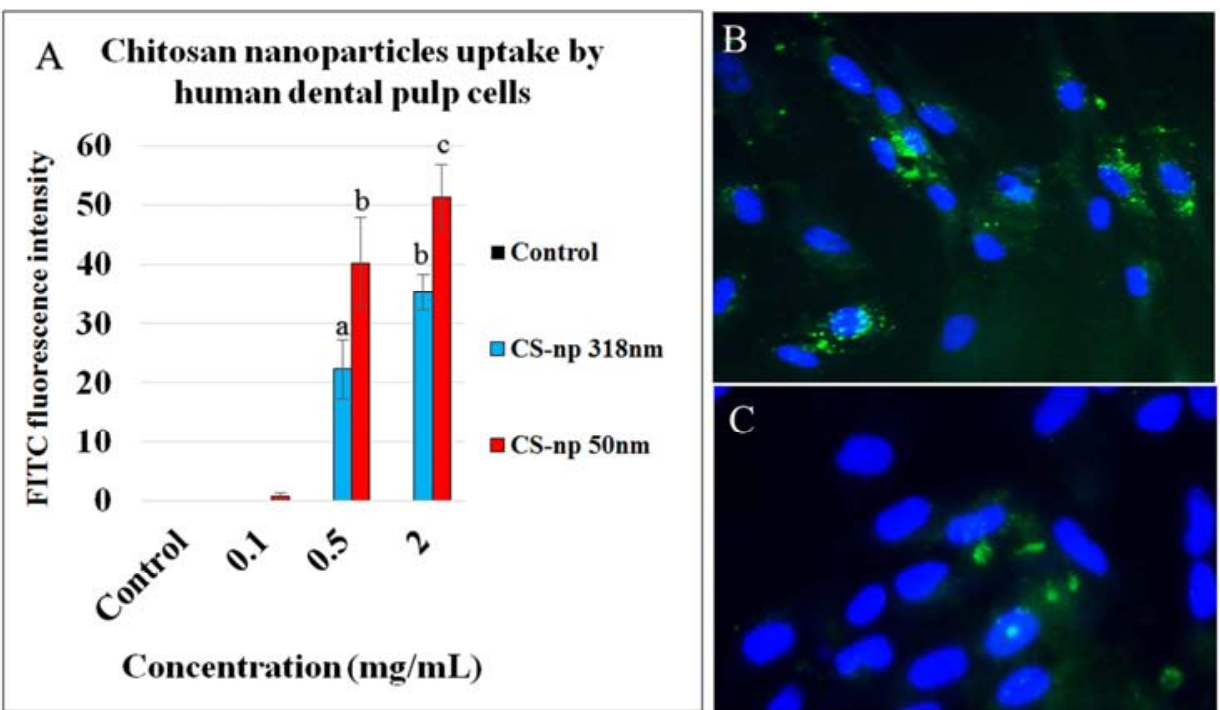

Figure 2. The uptake of various sizes of chitosan nanoparticles at different doses, by human dental pulp cells is illustrated in (A). The data is presented as means of triplicates with error bars indicating the standard deviations. Groups labeled with different letter differ statistically as compared to the control group and other study groups $(P<0.05)$. An image obtained from fluorescence microscope shows the uptake of $50 \mathrm{~nm}$ chitosan nanoparticles by human dental pulp cells is shown in (B). Some of the nanoparticles were accumulated on cytoplasm and others were on the nuclei. The Uptake of 318 nm chitosan nanoparticles by human dental pulp cells is shown in (C). The image shows that the uptake of $318 \mathrm{~nm}$ chitosan was less than $50 \mathrm{~nm}$ chitosan. The images were taken by epifluorescence microscope using DAPI filter for blue and FITC filter for green, at a magnification of 40X.
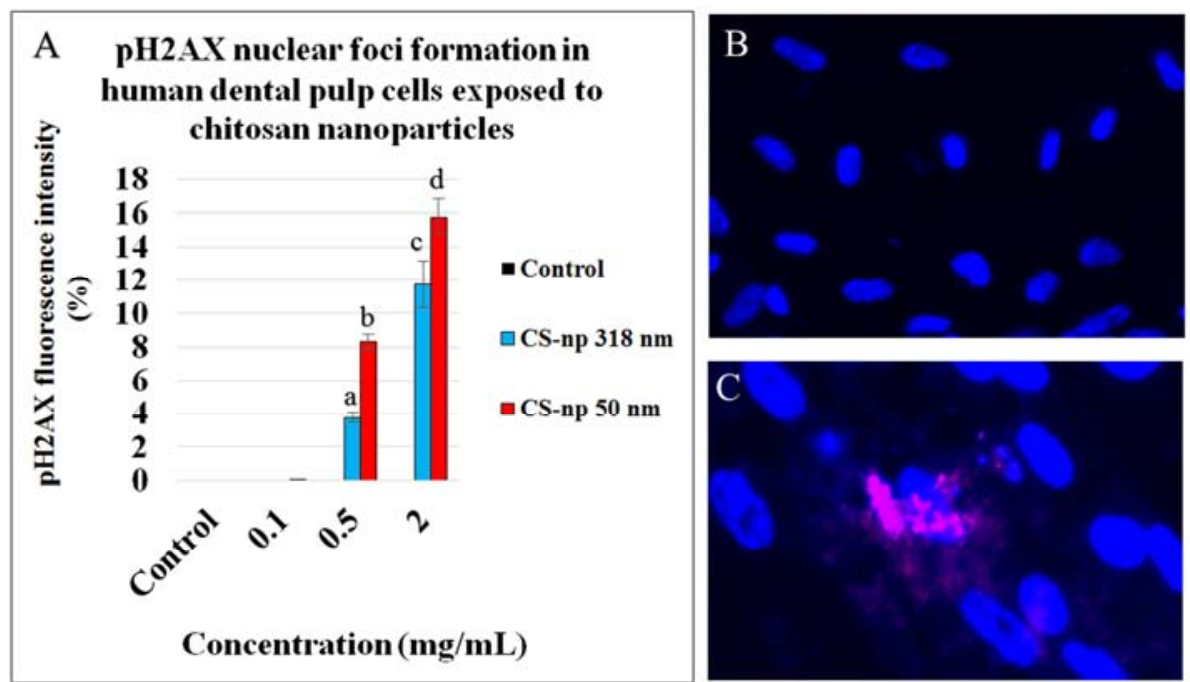

Figure 3. The formation of phosphorylated H2AX histones in human dental pulp cells exposed to various sizes of chitosan nanoparticles at different doses is shown in (A). The data is presented as means of triplicates with error bars indicating the standard deviations. Groups labeled with different letter differ statistically as compared to the control group and other study groups $(P<0.05)$. Epifluorescence images show absence of phosphorylated H2AX histone in the untreated cells $(B)$. Image $(C)$ shows formation of nuclear foci, which is an indication of DNA double-strand breaks, in human dental pulp cells exposed to chitosan nanoparticles. The images were taken by epifluorescence microscope using DAPI filter for blue and Cy 5 filer for red, at a magnification of $40 X$. 


\subsection{PH2AX Expression in Human Dental Pulp Cells Exposed to Various Sizes and Concentrations of Chitosan Nanoparticles}

The effect of various sizes and concentrations of CSnanoparticles on the expression of $\mathrm{pH} 2 \mathrm{AX}$ histones in $\mathrm{hDPCs}$ is illustrated in Figure 3 (A, B, and C). It was noted that the concentration of $0.1 \mathrm{mg} / \mathrm{mL}$ for both sizes, $50 \mathrm{~nm}$ and 318 $\mathrm{nm}$, showed no significant impact on the level of $\mathrm{pH} 2 \mathrm{AX}$ expression as compared to the control $(P=0.44)$. However, a significant upregulation of $\mathrm{pH} 2 \mathrm{AX}$ was observed in cells treated with $50 \mathrm{~nm}$ and $318 \mathrm{~nm}$ CS-nanoparticles as the dose was increased up to $0.5 \mathrm{mg} / \mathrm{mL}$ and $2 \mathrm{mg} / \mathrm{mL}$ in comparison with the control $(P<0.05)$. At both concentrations, 0.5 $\mathrm{mg} / \mathrm{mL}$ and $2 \mathrm{mg} / \mathrm{mL}$, CS-nanoparticles sized $50 \mathrm{~nm}$ significantly induced more $\mathrm{pH} 2 \mathrm{Ax}$ formation as compared to $318 \mathrm{~nm} \quad(\mathrm{P}<0.05)$. Epifluorescence microscope further confirmed the formation of nuclear foci in the cells that were exposed to higher concentrations of chitosan nanoparticles as seen in Figure 3 (B and C).

\subsection{Micronuclei and Nuclear Buds Induced by Chitosan Nanoparticles}

The formation of chromosomal abnormalities in the control group and the nanoparticles treated groups and the results of the cytokinesis-block micronucleus assay is summarized in Figure 4 (A. B, and C). The result of this experiment further corroborated the absence of chromosomal damage in cells treated with $0.1 \mathrm{mg} / \mathrm{mL} \mathrm{CS}$-nanoparticles, as the frequency of micronuclei and nuclear buds revealed by these cells were comparable with the control group $(P>$ 0.05). Nevertheless, the extent of DNA damage was significantly higher in cells treated with CS-nanoparticles at concentrations of $0.5 \mathrm{mg} / \mathrm{mL}$ and $2 \mathrm{mg} / \mathrm{mL}(P<0.0001)$. It was also observed that $50 \mathrm{~nm}$ groups induced higher frequencies of micronuclei and nuclear buds as compared to 318 nm groups $(P<0.05)$.

\begin{tabular}{|c|c|c|c|c|}
\hline $\mathrm{A}$ & $\begin{array}{l}\text { Number of micronuclei per } \\
1000 \text { cells }(\text { Mean } \pm \text { SD) }\end{array}$ & $\begin{array}{l}\text { Percentage of } \\
\text { micronuclei }\end{array}$ & $\begin{array}{l}\text { Number of nuclear buds } \\
\text { per } 1000 \text { cells }\end{array}$ & $\begin{array}{l}\text { Percentage of } \\
\text { nuclear bud }\end{array}$ \\
\hline $0 \mathrm{mg} / \mathrm{mL}$ & $8 \pm 3^{a}$ & $0.8 \%$ & $7 \pm 0.6^{a}$ & $0.7 \%$ \\
\hline $0.1 \mathrm{mg} / \mathrm{mL}, 50 \mathrm{~nm}$ & $10 \pm 2^{a}$ & $1 \%$ & $7 \pm 2^{a}$ & $0.7 \%$ \\
\hline $0.5 \mathrm{mg} / \mathrm{mL}, 50 \mathrm{~nm}$ & $117 \pm 12^{b}$ & $11.70 \%$ b & $108 \pm 6^{b}$ & $10.8 \%{ }^{b}$ \\
\hline $2 \mathrm{mg} / \mathrm{mL}, 50 \mathrm{~nm}$ & $171 \pm 8^{c}$ & $17.10 \%$ & $135 \pm 10^{c}$ & $13.5 \%$ \\
\hline $0.1 \mathrm{mg} / \mathrm{mL}, 318 \mathrm{~nm}$ & $6 \pm 1.2^{\mathrm{a}}$ & $0.60 \%{ }^{a}$ & $5 \pm 2^{a}$ & $0.5 \%$ \\
\hline $0.5 \mathrm{mg} / \mathrm{mL}, 318 \mathrm{~nm}$ & $58 \pm 10^{d}$ & $6 \%$ & $70 \pm 15^{d}$ & $7 \%$ \\
\hline $2 \mathrm{mg} / \mathrm{mL}, 318 \mathrm{~nm}$ & $118 \pm 7^{b}$ & $12 \%^{b}$ & $110 \pm 9 b$ & $11 \%$ \\
\hline
\end{tabular}
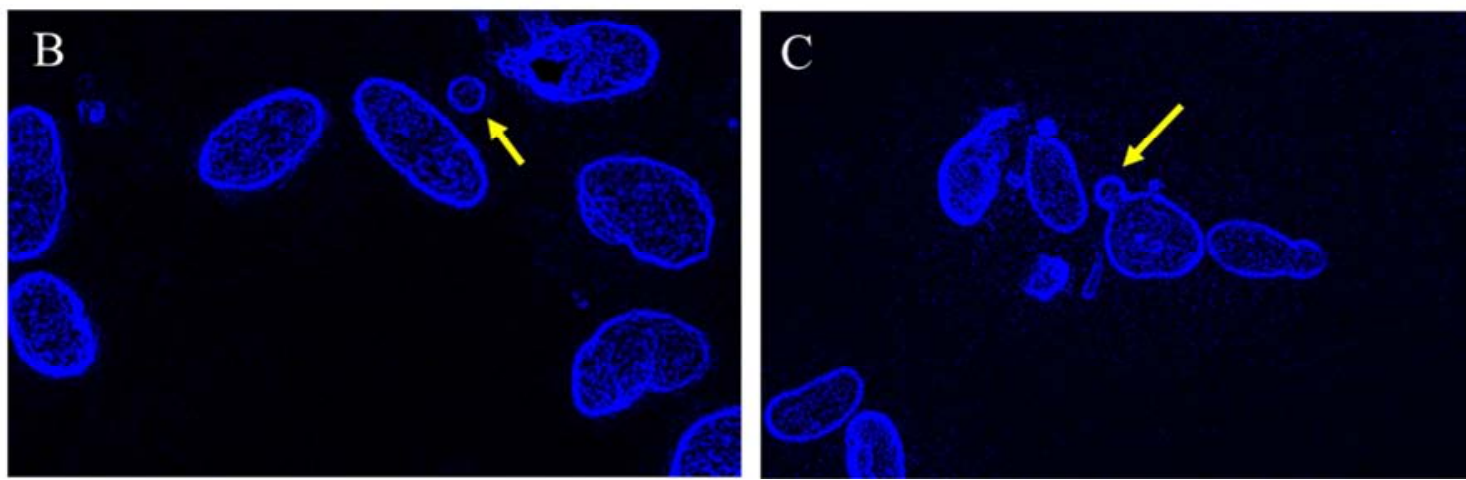

Figure 4. The table shows the results of cytokinesis-block micronucleus assay of human dental pulp cells exposed to various sizes and doses of chitosan nanoparticles for 24 hours. The values with different alphabetic subscript differ statistically as compared to the control group and other study groups within the same column $(P<0.05)$. Images $(B)$ and $(C)$ showed the formation of micronuclei and nuclear buds, respectively, formed in the human dental pulp cells exposed to chitosan nanoparticles. The images were taken by epifluorescence microscope using DAPI filer at a magnification of $40 X$.

\section{Discussion}

With the current advancements in Dentistry and Endodontics, nanotechnology utilizing metallic, inorganic or organic nanoparticles, appear to have promising potential. Nevertheless, it is imperative to assess the safety of these nanoparticles prior to any clinical implementation. There are some reports that demonstrated toxicity associated with metallic and inorganic nanoparticles [18, 19]. Therefore, nanoparticle derived from organic sources, such as Chitosan, has been the focus of a number of studies reporting its potential application in Endodontics [9, 20-23]. However, a study published by the current authors demonstrated a dose-dependent and sizeassociated cytotoxicity of chitosan nanoparticles cultured with human dental pulp cells for 14 days [13]. The present study was designed to further assess the cellular uptake and genotoxicity of different sizes and concentrations of chitosan nanoparticles on human dental pulp cells.

The finding of the present study clearly showed that $50 \mathrm{~nm}$ chitosan induced higher DNA-damaging effect as compared to $350 \mathrm{~nm}$ chitosan. In order to accurately assess the Nanoeffect of chitosan, it was crucial to control the particle size in the culture medium. In a complex biological solution, suspended nanoparticles are normally confronted with several forces. Whenever the exerted van-der-Waals forces 
on nanoparticles exceed the repulsive electrostatic force, the nanoparticles tend to agglomerate [24]. Also, nanoparticles surface charge [25], concentration [26], size [27], structure [28], chemical composition [28], and organic constituents in culture medium [24] appeared to be factors contributed to the formation of large agglomerates. Formation of micro-meter large agglomerates in culture media creates a challenging issue as this could complicate the researcher's ability to deduce the nanoparticles interaction with living cells. Herein, the ultrasonic cavitation effectively disintegrated the large agglomerates in the culture medium and kept the nanoparticles stable for three days. The higher genotoxicity associated with $50 \mathrm{~nm}$ chitosan can be referred to the ability of these nanoparticles to penetrate the dental pulp cells more effectively than $350 \mathrm{~nm}$ chitosan.

Cellular uptake of different sizes and concentrations of chitosan nanoparticles was tested by tagging the nanoparticles with FITC fluorescent stain. This tagging process is based on the covalent bond that forms between active amino groups in chitosan with isothiocyanate group in FITC which has been shown to resist the photobleaching effect more than the pure FITC stain [14]. The FITC tagging method demonstrated that the $50 \mathrm{~nm}$ nanoparticles were engulfed by pulp cells more than $350 \mathrm{~nm}$ at all tested concentrations. This can be explained by the fact that smaller nanoparticles have more ability to penetrate the cellular membrane than larger nanoparticles. Furthermore, there was a dose-dependent response in both size groups. This method was also used with similar findings by Huang et al, which demonstrated the cellular internalization of chitosan nanoparticles in epithelial cells [29]. Concentrationdependent uptake of chitosan nanoparticles might be due to the fact that the zeta-potential is decreased if the nanoparticles solution is diluted, which consequently reduces interaction between the positievely charged nanoparticles and the negatively charged cellular membrane..

DNA damage, which could be a potential cause for cellular death, was assessed as early as 24 hours from exposure to chitosan nanoparticles. The DNA damage in the present study was assessed by quantifying the frequencies of micronuclei, nuclear buds, and phosphorylated H2AX histones which are recognized indications for DNA doublestrands breaks [17, 30]. Micronuclei formation is a sign of chromosomal fragments that are left behind during anaphase nuclear division [17]. Nuclear bud formation is a sign of DNA amplification at the site of the nuclear damage that is being eliminated from the nucleus [17]. Only by blocking cell division using agents like cytochalasin-b, chromosomal abnormality can be detected microscopically by specific stain that has high affinity to DNA such as DAPI stain [17]. Moreover, when DNA double strands break occurs, a phosphorylation of a specific site on $\mathrm{H} 2 \mathrm{AX}$ histone will take place to recruit the repairing proteins [31]. Using antibody conjugated with florescent stain that specifically binds to the phosphorylated $\mathrm{H} 2 \mathrm{AX}$, areas of DNA double strand breaks can be accurately detected [31]. There is an evidence that these chromosomal abnormalities potentially can be transferred to the offspring cells during proliferation [32]. An experiment was done by Lodish et al, in 2000, where DNA was extracted from tumor cells and cultured with normal mouse fibroblasts which normally grow as a monolayer, because the normal fibroblasts stop dividing when they come in contact with other cells [32]. It was shown that some of the normal fibroblasts took up the mutated DNA and transformed into tumor cells by rapidly proliferating and forming a pile of cells in the culture dish [32]. In the present study, it was demonstrated that when the load concentration of CSnanoparticles increased up to $0.5 \mathrm{mg} / \mathrm{mL}$ and $2 \mathrm{mg} / \mathrm{mL}$, cellular uptake and DNA-damage was observed in hDPCs in dose-dependent and size-associated manners. Such finding is imperative in the clinical situation as it implies that the amount of chitosan nanoparticles leaching out of the dental material should not exceed $0.5 \mathrm{mg} / \mathrm{mL}$ to avoid genotoxicity on dental pulp.

The DNA-damage effect of chitosan nanoparticles on human dental pulp cells was not reported previously in the literature. Nevertheless, genotoxicity of different types of nanoparticles has been previously described in the literature on cells that are sensitive in microenvironments. A study conducted by Chou et al. showed that the micronuclei were expressed in high quantity by cervical cancer cells (Hela cells) after exposure to several concentrations of silver nanoparticles suspended in hydrogel [33]. Another report also suggested an analogous size-dependent genotoxic effect induced by silica nanoparticles cultured with human umbilical vein endothelial cells [34].

Another key finding presented in this paper is the limited uptake and the absence of genotoxicity of CS-nanoparticles at a concentration of $0.1 \mathrm{mg} / \mathrm{mL}$ on human dental pulp cells. Notably, in previously published antimicrobial studies, CSnanoparticles were applied at doses higher than $0.1 \mathrm{mg} / \mathrm{mL}$. A report published by Arancibia et al. presented that only at a concentration of $5 \mathrm{mg} / \mathrm{mL}$ were CS-nanoparticles efficacious in suppressing the growth of aggregatibacter actinomycetemcomitans and porphyromonas gingivitis, the bacteria which are associated with periodontal diseases [35]. Likewise, the findings of Alisghari et al. indicated that the minimum inhibition concentration of CS-nanoparticles against cariogenic S. mutans, S. sobrinus, and S. salivarius was found to be at $0.6 \mathrm{mg} / \mathrm{mL}$ with minimum bacterial concentration observed at least with $1.2 \mathrm{mg} / \mathrm{mL}$ and 2.5 $\mathrm{mg} / \mathrm{mL}$ concentrations check [36]. Nevertheless, studies have shown that the antimicrobial activity of CS-nanoparticles at a dose of $0.1 \mathrm{mg} / \mathrm{mL}$ can be boosted by alternative methods such as structural modification of the nanoparticles or implementing photodynamic activation [37, 38].

\section{Conclusion}

The present study demonstrated that, at a dose of 0.1 $\mathrm{mg} / \mathrm{mL}$, chitosan nanoparticles showed limited uptake by human dental pulp cells with no genotoxicity. However, chitosan nanoparticles at higher concentrations, $0.5 \mathrm{mg} / \mathrm{mL}$ and $2 \mathrm{mg} / \mathrm{mL}$, were able to internalize the dental pulp cells 
and induced DNA damage in dose-dependent and size associated manners.

\section{References}

[1] Divya K., Vijayan Smitha, George Tijith K., Jisha M. S. Antimicrobial properties of chitosan nanoparticles: Mode of action and factors affecting activity. Fibers Polym 2017; 18 (2): 221-30. Doi: 10.1007/s12221-017-6690-1.

[2] Kishen Anil, Shi Zhilong, Shrestha Annie, Neoh Koon Gee. An Investigation on the Antibacterial and Antibiofilm Efficacy of Cationic Nanoparticulates for Root Canal Disinfection. J Endod 2008; 34 (12): 1515-20. Doi: 10.1016/j.joen.2008.08.035

[3] Chavez de Paz L. E., Resin A., Howard K. A., Sutherland D. S., Wejse P. L. Antimicrobial Effect of Chitosan Nanoparticles on Streptococcus mutans Biofilms. Appl Environ Microbiol 2011; 77 (11): 3892-5. Doi: 10.1128/AEM.02941-10.

[4] Del Carpio-Perochena Aldo, Kishen Anil, Shrestha Annie, Bramante Clovis Monteiro. Antibacterial Properties Associated with Chitosan Nanoparticle Treatment on Root Dentin and 2 Types of Endodontic Sealers. J Endod 2015; 41 (8): 1353-8. Doi: 10.1016/j.joen.2015.03.020.

[5] del Carpio-Perochena Aldo, Kishen Anil, Felitti Rafael, et al. Antibacterial Properties of Chitosan Nanoparticles and Propolis Associated with Calcium Hydroxide against Singleand Multispecies Biofilms: An In Vitro and In Situ Study. J Endod 2017; 43 (8): 1332-6. Doi: 10.1016/j.joen.2017.03.017.

[6] Travan Andrea, Marsich Eleonora, Donati Ivan, et al. Silverpolysaccharide nanocomposite antimicrobial coatings for methacrylic thermosets. Acta Biomater 2011; 7 (1): 337-46. Doi: 10.1016/j.actbio.2010.07.024.

[7] Jiang Li Qun, Wang Ting Yu, Webster Thomas J., et al. Intracellular disposition of chitosan nanoparticles in macrophages: Intracellular uptake, exocytosis, and intercellular transport. Int J Nanomedicine 2017; 12: 6383-98. Doi: $10.2147 / \mathrm{IJN}$.S142060.

[8] Gigault Julien, Halle Alexandra ter, Baudrimont Magalie, et al Current opinion: What is a nanoplastic? Environ Pollut 2018; 235: 1030-4. Doi: 10.1016/j.envpol.2018.01.024.

[9] Zhang Xu, Li Yanqiu, Sun Xiaoxi, et al. Biomimetic remineralization of demineralized enamel with nanocomplexes of phosphorylated chitosan and amorphous calcium phosphate. J Mater Sci Mater Med 2014; 25 (12): 2619-28. Doi: 10.1007/s10856-014-5285-2.

[10] Stanislawski L, Carreau J P, Pouchelet M, Chen Z H, Goldberg M. In vitro culture of human dental pulp cells: some aspects of cells emerging early from the explant. Clin Oral Investig 1997; 1 (3): 131-40. Doi: 10.1007/s007840050024.

[11] Alonso M J, Calvo P, Remun C. Novel Hydrophilic Chitosan - Polyethylene Oxide Nanoparticles as Protein Carriers n. d.: $125-32$.

[12] Gan Quan, Wang Tao, Cochrane Colette, McCarron Paul. Modulation of surface charge, particle size and morphological properties of chitosan-TPP nanoparticles intended for gene delivery. Colloids Surfaces B Biointerfaces 2005; 44 (2-3): 65-73. Doi: 10.1016/j.colsurfb.2005.06.001.
[13] Alhomrany Rami, Zhang Chang, Chou Laisheng. Cytotoxic effect of chitosan nanoparticles on normal human dental pulp cells 2019; 3 (1): 1-9.

[14] Qaqish Roula B, Amiji Mansoor M. Synthesis of a - uorescent chitosan derivative and its application for the study of chitosan \pm mucin interactions 1999; 38: 99-107.

[15] Patiño Tania, Soriano Jorge, Barrios Lleonard, Ibáñez Elena, Nogués Carme. Surface modification of microparticles causes differential uptake responses in normal and tumoral human breast epithelial cells. Nat Publ Gr 2015; (December 2014): 112. Doi: $10.1038 /$ srep 11371.

[16] Landuyt Kirsten Van, Styllou Panorea, Rothmund Lena, et al. Cytotoxicity and induction of DNA double-strand breaks by components leached from dental composites in primary human gingival fibroblasts. Dent Mater 2013; 29 (9): 971-9. Doi: 10.1016/j.dental.2013.07.007.

[17] Thomas Philip, Fenech Michael. Cytokinesis-block micronucleus cytome assay in lymphocytes. Methods Mol Biol 2011; 682: 217-34. Doi: 10.1007/978-1-60327-409-8 16.

[18] HAMIDA R. S.; ALBASTER G.; BIN-MEFERIJ M. M. Oxidative Stress and Apoptotic Responses Elicited by. Cancers (Basel) 2020; 12 (8): 1-25.

[19] Azouz Rehab A., Korany Reda M. S. Toxic Impacts of Amorphous Silica Nanoparticles on Liver and Kidney of Male Adult Rats: an In Vivo Study. Biol Trace Elem Res 2020. Doi: 10.1007/s12011-020-02386-3.

[20] Shrestha Suja, Diogenes Anibal, Kishen Anil. Temporalcontrolled Dexamethasone Releasing Chitosan Nanoparticle System Enhances Odontogenic Differentiation of Stem Cells from Apical Papilla. J Endod 2015; 41 (8): 1253-8. Doi: 10.1016/j.joen.2015.03.024

[21] Del Carpio-Perochena A, Bramante C M, Duarte M A, de Moura M R, Aouada F A, Kishen A. Chelating and antibacterial properties of chitosan nanoparticles on dentin. Restor Dent Endod 2015; 40 (3): 195-201. Doi: 10.5395/rde.2015.40.3.195.

[22] Shrestha Suja, Diogenes Anibal, Kishen Anil. Temporalcontrolled release of bovine serum albumin from chitosan nanoparticles: effect on the regulation of alkaline phosphatase activity in stem cells from apical papilla. J Endod 2014; 40 (9): 1349-54. Doi: 10.1016/j.joen.2014.02.018.

[23] Dasilva Luis, Finer Yoav, Friedman Shimon, Basrani Bettina, Kishen Anil. Biofilm formation within the interface of bovine root dentin treated with conjugated chitosan and sealer containing chitosan nanoparticles. J Endod 2013; 39 (2): 24953. Doi: 10.1016/j.joen.2012.11.008.

[24] Bruinink Arie, Wang Jing, Wick Peter. Effect of particle agglomeration in nanotoxicology. Arch Toxicol 2015; 89 (5): 659-75. Doi: 10.1007/s00204-015-1460-6.

[25] Allouni Zouhir E., Cimpan Mihaela R., Høl Paul J., Skodvin Tore, Gjerdet Nils R. Agglomeration and sedimentation of $\mathrm{TiO} 2$ nanoparticles in cell culture medium. Colloids Surfaces B Biointerfaces 2009; 68 (1): 83-7. Doi: 10.1016/j.colsurfb.2008.09.014.

[26] Bae Eunjoo, Park Hee Jin, Lee Jeongjin, et al. Bacterial cytotoxicity of the silver nanoparticle related to physicochemical metrics and agglomeration properties. Environ Toxicol Chem 2010; 29 (10): 2154-60. Doi: 10.1002/etc.278. 
[27] Andersson Per Ola, Lejon Christian, Ekstrand-Hammarström Barbro, et al. Polymorph- and size-dependent uptake and toxicity of $\mathrm{TiO} 2$ nanoparticles in living lung epithelial cells. Small 2011; 7 (4): 514-23. Doi: 10.1002/smll.201001832.

[28] Ahamed Maqusood, Karns Michael, Goodson Michael, et al. DNA damage response to different surface chemistry of silver nanoparticles in mammalian cells. Toxicol Appl Pharmacol 2008; 233 (3): 404-10. Doi: 10.1016/j.taap.2008.09.015.

[29] Huang Min, Ma Zengshuan, Khor Eugene, Lim Lee Yong. Uptake of FITC-chitosan nanoparticles by A549 cells. Pharm Res 2002; 19 (10): 1488-94. Doi: 10.1023/A:1020404615898.

[30] Kuo Linda J., Yang Li Xi. $\gamma-\mathrm{H} 2 \mathrm{AX}-\mathrm{A}$ novel biomaker for DNA double-strand breaks. In Vivo (Brooklyn) 2008; 22 (3): 305-10.

[31] Sharma Arishya, Singh Kamini, Almasan Alexandru. Histone H2AX Phosphorylation: A Marker for DNA Damage 2012; 920: 613-26. Doi: 10.1007/978-1-61779-998-3 40.

[32] Shuga J., Zhang J., Samson L. D., Lodish H. F., Griffiths L. G. In vitro erythropoiesis from bone marrow-derived progenitors provides a physiological assay for toxic and mutagenic compounds. Proc Natl Acad Sci U S A 2007; 104 (21): 873742. Doi: 10.1073/pnas.0701829104.

[33] Xu Liming, Li Xuefei, Takemura Taro, Hanagata Nobutaka, Wu Gang, Chou Laisheng L. Genotoxicity and molecular response of silver nanoparticle (NP)-based hydrogel. J Nanobiotechnology 2012; 10: 1-11. Doi: 10.1186/1477-3155-10-16.
[34] Zhou Furong, Liao Fen, Chen Lingying, Liu Yuanfeng, Wang Wuxiang, Feng Shaolong. The size-dependent genotoxicity and oxidative stress of silica nanoparticles on endothelial cells. Environ Sci Pollut Res 2019; 26 (2): 1911-20. Doi: 10.1007/s11356-018-3695-2.

[35] Arancibia R., Maturana C., Silva D., et al. Effects of chitosan particles in periodontal pathogens and gingival fibroblasts. J Dent Res 2013; 92 (8): 740-5. Doi: $10.1177 / 0022034513494816$.

[36] Aliasghari Azam, Khorasgani Mohammad Rabbani, Vaezifar Sedigheh, Rahimi Fateh, Younesi Habibollah, Khoroushi Maryam. Evaluation of antibacterial efficiency of chitosan and chitosan nanoparticles on cariogenic streptococci: An in vitro study. Iran J Microbiol 2016; 8 (2): 93-100. Doi: 10.5281/zenodo.3342597.

[37] Covarrubias Cristian, Trepiana Diego, Corral Camila. Synthesis of hybrid copper-chitosan nanoparticles with antibacterial activity against cariogenic Streptococcus mutans. Dent Mater J 2018; 37 (3): 379-84. Doi: 10.4012/dmj.2017195.

[38] Chen Chueh Pin, Chen Chin Tin, Tsai Tsuimin. Chitosan nanoparticles for antimicrobial photodynamic inactivation: Characterization and in vitro investigation. Photochem Photobiol 2012; 88 (3): 570-6. Doi: 10.1111/j.17511097.2012.01101.x. 